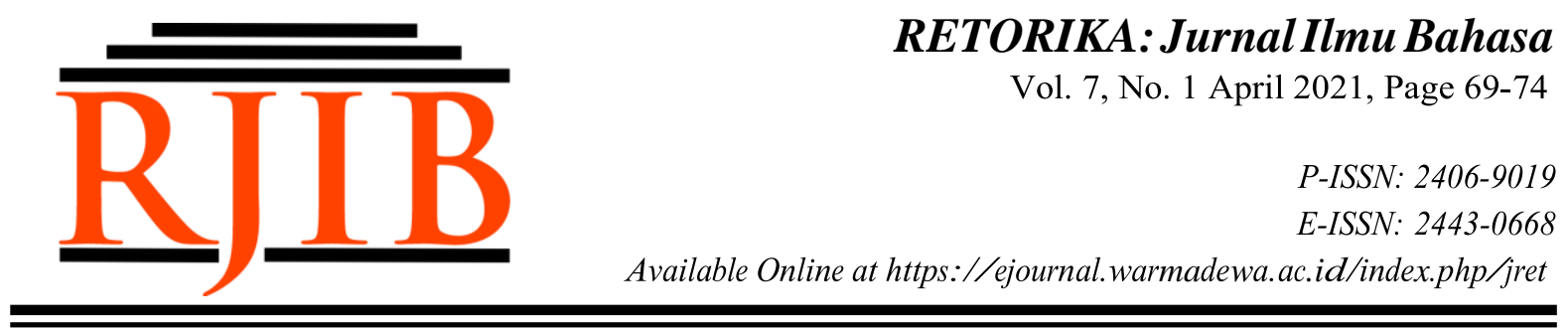

\title{
The Implemetation of Contextual Redefinition Strategy for the Improvement of Reading Skill of STMIK STIKOM Indonesia's Students
}

\author{
Maria Osmunda Eawea Monny*, Ni Putu Dian Indra Pratiwi \\ STMIK STIKOM Indonesia \\ *maria.monny@stiki-indonesia.ac.id
}

\begin{tabular}{|l|}
\hline How to cite (in APA style): \\
Monny, M. O. E. \& Pratiwi, N. P. D. I. (2021). The Implemetation of Contextual Redefinition Strategy for the Improvement \\
of Reading Skill of STMIK STIKOM Indonesia's Students. Retorika: Jurnal Ilmu Bahasa, 7(1), 69-74. doi: \\
https://doi.org/10.22225/jr.7.1.2880.69-74
\end{tabular}

Abstract- One way of improving understanding of English for Specific Purposes is through Contextual Redefinition Strategy (CRS). The implementation of CRS is meant to enhance the understanding of students of STMIK STIKOM Indonesia mostly in computers and business terms. The implementation of CRS is done through Classroom Action Research (CAR) in 3 stages of activities; those are pre-implementation, Middle Test (Cycle I) and Final Test (Cycle II). Besides, questionnaire is used with the purpose to know students' attitude towards CRS' implementation. The results of reading test on pre-implementation show that out of 40 students, there were 26 students did not get the lowest score 55 as the passing score of the college. After the explanation of CRS stages, middle and Final Tests tested the topics of reading texts on computers and business through search for clues in nearby words or sentences, and paragraphs of a text. Specific context clues that should be explicitly considered to understand the meaning of the sentences are definition/explanation, synonym/restatement, antonym/contrast, inference/general, and punctuation context. The results of Middle Test show that 22 students could get the score above 55, however most of students made mistakes in making redefinition based on inference/general and punctuation context. The results of Cycle II show that all students can score above 55. Besides, the results show that the students could improve their understanding for inference/general and punctuation context. The questionnaire shows that the students are motivated to acquire more and more vocabularies based on the needs for computer and business terms. The implementation of CRS does not only improve students' ability to understand English based on its context but also enrich the vocabularies.

Keywords: foreign language, reading, CRS

\section{INTRODUCTION}

In acquiring a language, there are 4 skills need to be mastered by its speakers; those skills are listening, speaking, reading and writing. Out of these 4 skills in a narrow scope of learning a foreign language, reading is one of the most difficult skills to be mastered due to the environment and lack of vocabularies. As a foreign language in Indonesia, most students will find it difficult to grasp the meaning of English through the texts given mostly for specific purposes which using specific terms. According to Trioke (2006), the labeling of reading and listening as "receptive" (as opposed to "productive") activities does not imply that L2 learners perform them passively and without effort. Learners must actively participate in creating meaning from L2 input, or else writing 
remains merely marks on paper and speech remains only a stream of noise that people emit through their mouths. Furthermore, Trioke (2006) states that productive activities for language use involve essentially the same topdown and bottom-up processes as those for reception. Production (like comprehension) of written or spoken language requires prior knowledge of vocabulary, morphology, phonology, syntax, and discourse structure to access words and combine them into phrases, clauses, and longer units of text.

Based on the data through the activities Reading 1 and Reading 2 of English Language I showed that students encountered difficulties in pronouncing the words and understood the meaning of the texts based on its context. This happened due to fewer acquaintances to English environment and lack of vocabularies in English.

According to Tierney, Dishner, \& Readence (1990), contextual redefinition is a strategy that emphasizes the importance of context in predicting and verifying word meaning. It also provides activities that can help students connect word with their prior knowledge which emphasizes comprehension monitoring. The strategy is also actively allows the students involves in learning which are more likely to result in significant vocabulary growth. In other words, contextual redefinition is the strategy that involves context clue which aims to activate the prior knowledge especially word knowledge and to enhance more vocabulary.

Systemic functional grammar (SFG) or systemic functional linguistics (SFL) is a model of grammar developed by Michael Halliday in the 1960s. According to Halliday \& Matthiessen (2014), it is part of a broad social semiotic approach to language called systemic linguistics. The term "systemic" refers to the view of language as "a network of systems, or interrelated sets of options for making meaning". The term "functional" indicates that the approach is concerned with the contextualized, practical uses to which language is put, as opposed to formal grammar, which focuses on compositional semantics, syntax and word classes such as nouns and verbs. Furthermore, SFG is concerned primarily with the choices the grammar makes available to speakers and writers. These choices relate speakers' and writers' intentions to the concrete forms of a language. Traditionally the "choices" are viewed in terms of either the content or the structure of the language used. In additional, according to (Teich, 1999), SFG in language is analysed in three different ways (strata): semantics, phonology, and lexicogrammar. SFG presents a view of language in terms of both structure (grammar) and words (lexis). The term "lexicogrammar" describes this combined approach.

The implementation of English Language in Indonesia as foreign language has put it as a mandatory subject. Due to its implementation as academics purposes has caused some hidrances for students to acquire the language fully. Students will study it only to get better scores not better skills and as a result they will encoutered difficulties at the workplace or to continue their studies on higher level of education. English for Specifi Purposes (ESP) has taken imporant role in students' acquisitio and fluency of second and foreign language. According to Jordan (1997), authentic, genuine, real, natural or unsimplified are adjectives randomly used today in ESP to refer to texts or materials that can be used within languagelearning contexts but which were specifically written or developed for an audience other than language learners. Similarly, an authentic text would be a text "normally used in the students' specialist subject area: written by specialists for specialists".

\section{METHOD}

The approach in this research is action research using Classroom Action research (CAR). CAR is a research activity that is done to solve the problem in learning process based on cycle. In every cycle, there are four levels those are planning; acting; observing and reflection (Arikunto \& Suharsini, 2006). In pedagogy, especially in learning process, CAR has developed as an applied research. CAR is useful for the teachers/lecturers to improve the process and output in the classroom activities. The four levels are described as follows: 


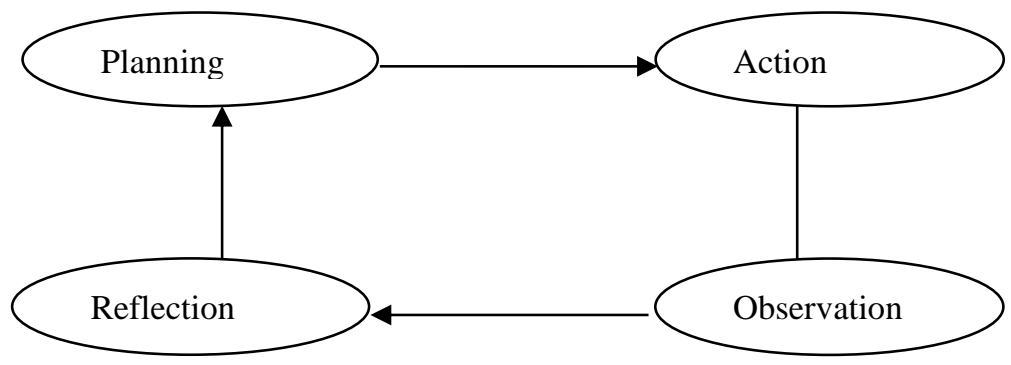

\section{Diagram 1 \\ Cycle of Classroom Action Research}

These four levels are done as a repeated cycle based on research needs. This cycle will be stopped if the aims of the research are achieved.

Data collecting technique of this research is done in three ways; those are observation, interview and literary research. The observation is done through Pre-Implementation, Cycle I (Mid Test) and Cycle II (Final Test) in order to get the valid data, interview is done through quesioner and literary research through Lesson Plan and other teaching administrations. The data gathered based on the interview through questioner filled by the students. The questioner contains questions about the difficulties in learning English and does CRS really help them in improving their understanding of English.

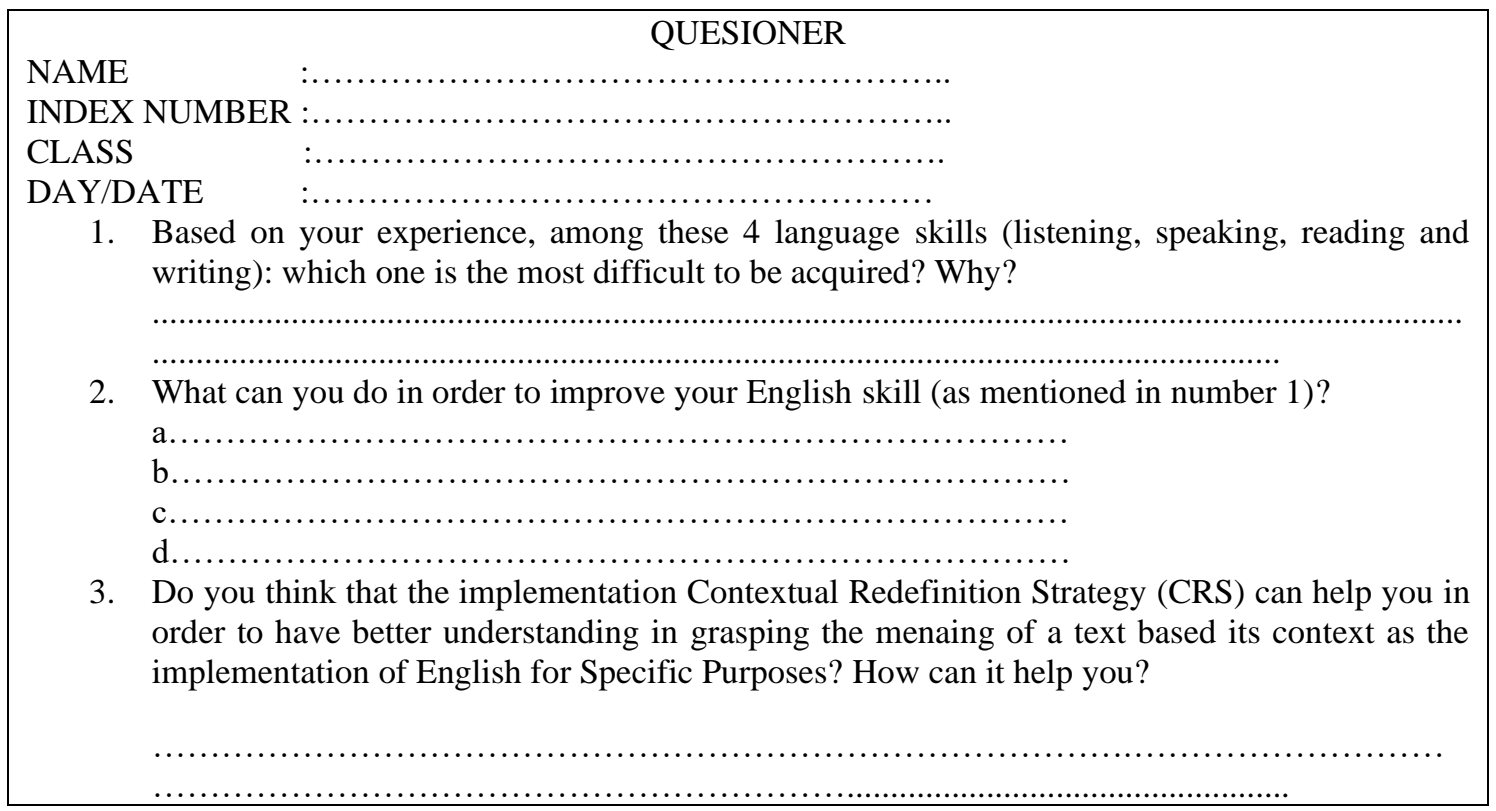

\section{RESULT AND DISCUSSION}

Observation of pre-action was conducted on Monday, 13 July 2020 in Class PP with the purpose to know the participation and how students understand English grammar through reading about computers and business. There were 40 students for the subject Bahasa Ingrgris IV before the implementation of CRS. After doing the intensive reading, the students were given the change to answer the questions based on the text. The results of pre-implementation on reading text on computers and business showed that the students found difficulties to understand the text based on its context. There were 26 students did not get the lowest score 55 as the passing score of the college. Based on the results of pre-implementation, CRS needed to be applied. The results of questioner showed out of 4 skills in English, reading skill is the most difficult to be acquired by the students. It showed about 12 out of 40 . While the second, third and fourth skills to be acquired are speaking (11 students), listening (9 students) and writing (8 students). While the efforts to improve reading skills are 1) increase reading activities in computers and business field (33\%); 2 ) enrich English vocabularies (25\%); 3) reading out loud for correct pronunciation (18\%); 4) 
take notes of the clues (15\%) and 5) guess the meaning (9\%). The graphs the questioners result are shown below:

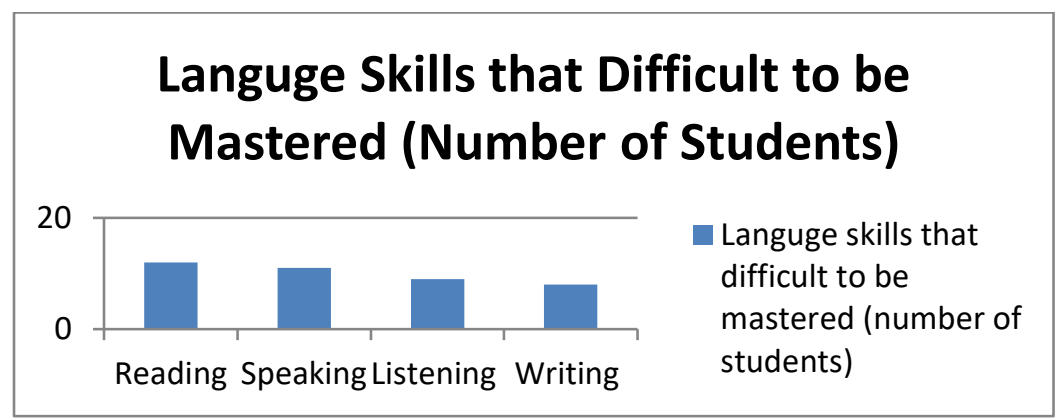

\section{Diagram 2 \\ Language Skills}

Cycle I was done on Middle Test on Wednesday; 29 July 2020, attended by 40 students. The students were given 2 texts. First text was about computers and the second was about business. The students were asked to understand the meaning of the sentences through 1) definition/explanation; synonym/restatement; 3) antonym/contrast; 4) inference/general and 5) punctuation context. There were 2 sentences taken from first and second texts where each sentence must be examined based on its context in 5 clues above. The results of Middle test are as follows:

1. Definition/explanation: for first text there were 28 students answered the clue correctly and 12 students answered it wrong. While for second text there were 25 students answered correctly and 15 students answered it wrong.

2. Synonym/restatement: for first text there were 24 students answered the clue correctly and 16 students answered it wrong. While for second text there were 23 students answered correctly and 17 students answered it wrong

3. Antonym/contrast: for first text there were 27 students answered the clue correctly and 13 students answered it wrong. While for second text there were 22 students answered correctly and 18 students answered it wrong.

4. Inference/general: for first text there were 20 students answered the clue correctly and 20 students answered it wrong. While for second text there were 19 students answered correctly and 21 students answered it wrong

5. Punctuation context: for first text there were 18 students answered the clue correctly and 22 students answered it wrong. While for second text there were 15 students answered correctly and 25 students answered it wrong. The results of Cycle I (Middle test) is shown in graph below:

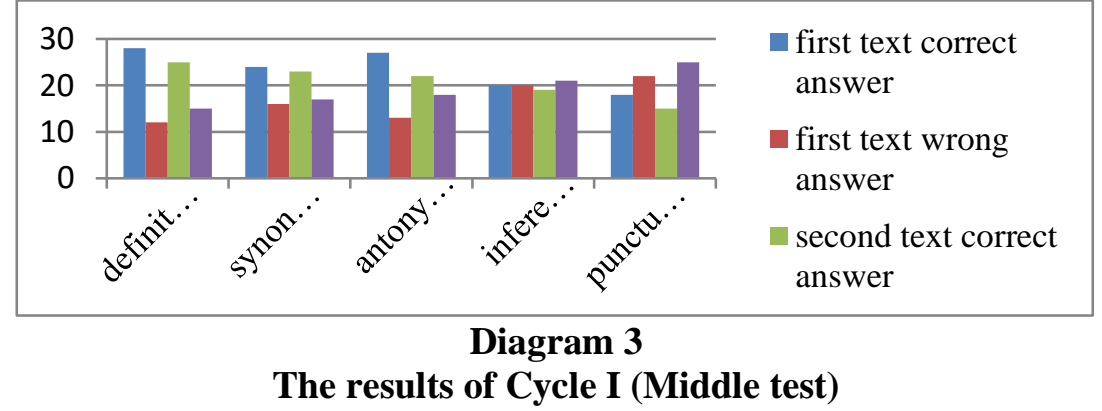

The results of Cycle I (Middle Test) showed that the students had better understanding based on the context of the reading and can answered the questions correctly more than 50\% for definition/explanation, synonym/restatement, and antonym/contrast. While for the clue inference/general and punctuation context 
needed to be improved due to the mistakes made more than $50 \%$. The results shows that out of 40 students 22 students can pass the passing scores 55. In order to improve students' level of CRS and to improve their reading skills, the learning process is conducted and Cycle II needed to be done in Final Test.

Cycle II was done on Final Test on Wednesday; 19 August 2020, it was attended by 40 students. The result shows that the level of students' understanding about CRS increases. The same as Cycle I, 2 texts were given to the students; first text was about computers and second text was about business. The students must answer the questions based on 5 clues as in Cycle I. The results of Final Test are as follows:

1. Definition/explanation: for first text there were 34 students answered the clue correctly and 6 students answered it wrong. While for second text there were 30 students answered correctly and 10 students answered it wrong.

2. Synonym/restatement: for first text there were 31 students answered the clue correctly and 9 students answered it wrong. While for second text there were 30 students answered correctly and 10 students answered it wrong.

3. Antonym/contrast: for first text there were 33 students answered the clue correctly and 7 students answered it wrong. While for second text there were 32 students answered correctly and 8 students answered it wrong.

4. Inference/general: for first text there were 25 students answered the clue correctly and 15 students answered it wrong. While for second text there were 27 students answered correctly and 13 students answered it wrong

5. Punctuation context: for first text there were 28 students answered the clue correctly and 12 students answered it wrong. While for second text there were 21 students answered correctly and 19 students answered it wrong. The result of Cycle II (Final Test) is shown in graph below:

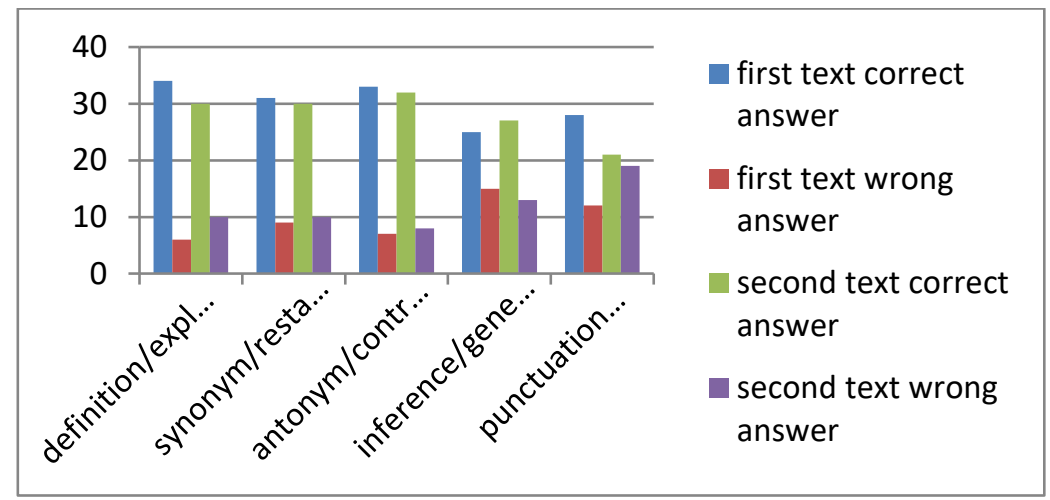

Diagram 4

The results of Cycle II (Final Test)

The results of Cycle II (Final Test) showed the progress for the clue inference/general and punctuation context where there were more than 50\% students can answer the questions correctly. The results show that the students can understand the lessons and got the score above 55 .

While from the questioner given to the students, the results showed that the implementation of CRS had helped the students with the feedback as follows: 1) it helps the students in increasing their vocabulary; 2) it triggers the students to read more English books about computers and business in order to understand more the reading based on its context; and 3) students are challenge to memorize English words in forms of synonyms and antonyms, which this way the will have double benefits out of one words or terms.

\section{CONCLUSION}

The questioner results showed that out of 4 skills in English, listening, speaking, reading and writing; reading skills is the most difficult language skills to be acquired by 13 out of 40 students. The second, third and fourth skills were speaking was found it is difficult by 10 students; listening were difficult to be mastered 
by 9 students and writing was difficult to be acquired by 8 students. While the efforts to improve reading skills are 1) increase reading activities in computers and business field (33\%); 2) enrich English vocabularies (25\%); 3) reading out loud for correct pronunciation $(18 \%)$; 4) take notes of the clues (15\%) and 5) guess the meaning (9\%). Furthermore, the implementation of CRS had helped the students with the feedback as follows: 1) it helps the students in increasing their vocabulary; 2) it triggers the students to read more English books about computers and business in order to understand more the reading based on its context; and 3) students are challenge to memorize English words in forms of synonyms and antonyms, which this way the will have double benefits out of one words or terms.

The implementation of CRS had helped the students in improving students reading skills where they were able to understand the reading passage based on its context. By doing the CRS, the students also can develop more and understand English better because they had enriched their vocabularies. The implementation of CRS was done in three stages those were: pre-implementation; Mid Test (Cycle I) and Final Test (Cycle II). In order to measure students' progress, five clues of CRS are used those are 1) definition/explanation; 2) synonym/restatement; 3) antonym/contrast; 4) inference/general; and 5) punctuation context.

The implementation of CRS has improved students' reading skill through the context of a text that can be seen through preimplementation, Middle Test (Cycle I) and Final Test (Cycle II). The results of preimplementation on reading text on computers and business showed that the students found difficulties to understand the text based on its context. There were 26 students did not get the lowest score 55 as the passing score of the college. The results of Cycle I (Middle Test) showed the improvement of students understanding based on the context of the reading and can answered the questions correctly more than $50 \%$ for definition/explanation, synonym/restatement, and antonym/contrast. While for the clue inference/general and punctuation context needed to be improved due to the mistakes made more than $50 \%$. The results shows that out of 40 students 22 students can pass the passing scores 55. The results of Cycle II (Final Test) showed the progress for the clue inference/general and punctuation context where there were more than $50 \%$ students can answer the questions correctly. The results show that the students can understand the lessons and got the score above 55.

\section{REFERENCES}

Arikunto, \& Suharsini. (2006). Penelitian Tindakan Kelas. Jakarta: PT Bumi Aksara.

Halliday, M. A. K., \& Matthiessen, C. M. I. M. (2014). Halliday's Introduction to Functional Grammar. Materials Science (4th ed.). London: Routledge.

Jordan, R. R. (1997). English for Academic Purposes. A Guide and Resource Book for Teachers. Cambridge: Cambridge University Press.

Teich, E. (1999). Systemic Functional Grammar in Natural Language Generation. London: Cassell.

Tierney, R. J., Dishner, E. K., \& Readence, J. E. (1990). Reading Strategies and Practices a Compedium (3rd ed.). Massachusetts: Allyn and Bacon. 